\title{
RESEARCH
}

Open Access

\section{The influence of cultivation frequency on weed species composition and diversity in flood recession farming in the Okavango Delta, Botswana}

\author{
Modise Nthaba*, Keotshephile Kashe(i) and Michael Murray-Hudson
}

\begin{abstract}
Introduction: Flood recession farming, locally known as molapo farming, is an important livelihood activity for the subsistence farming community around the Okavango Delta. The study was aimed at investigating the influence of cultivation frequency on non-crop species composition. It was carried out in the peripheral settlements of Shorobe, Makalamabedi and Lake Ngami.

Methods: Vegetation sampling was conducted from March to April 2016 in 36 fields of varying historical cultivation frequencies. The cultivation frequencies were 5, 10 and 15 years with an uncropped control site. Sampling was done in $1-\mathrm{m}^{2}$ quadrats placed $10 \mathrm{~m}$ apart along a line transect. Shannon's diversity and equitability indices were used to compare diversity for each cultivation frequency within and across the study sites. The Kruskal-Wallis test was used to investigate significant differences in diversity between cultivation frequencies. Rank of abundance was used to determine the association of weeds with the cultivation frequencies.

Results: Cultivation frequency did not influence species diversity $(p>0.05)$ at either Lake Ngami or Shorobe. Species evenness was significantly different $(p<0.05)$ between the cultivation frequencies at Shorobe, but not at either Makalamabedi or Lake Ngami. There was a significant difference $(p<0.05)$ in diversity indexes across the four cultivation frequencies. The 5-year frequency recorded the highest median score $(\mathrm{Md}=1.352)$ while the 15-year frequency recorded the lowest median score $(\mathrm{Md}=1.035)$. Corchorus tridens was the most abundant noncrop species at the 5- and 15-year frequencies. Cynodon dactylon was most abundant in the 10-year frequency while Cyperus esculentus was most abundant in uncropped fields.

Conclusions: Cultivation frequency influenced weed species diversity and composition in flood recession farming. Flood recession farming fields were dominated by common weed species which are also troublesome in dryland arable farming. Uncropped sites were composed of wetland species that tolerate some dry periods or seasonal flood plains.
\end{abstract}

Keywords: Flood recession farming, Cultivation frequency, Species composition, Species diversity

\footnotetext{
* Correspondence: kkashe@ub.ac.bw

University of Botswana, Okavango Research Institute, Private Bag 285, Maun,

Botswana
} 


\section{Introduction}

Disturbance is a distinct event that can modify the composition of an ecosystem and plant community and may also influence resource availability or the physical environment (Powell 2000; Hobbs and Humphries 1995). For instance, cultivation can disrupt the soil and existing plant communities facilitating invasion of some plant species while others may fail to grow in the new or modified environment. Areas such as agro-ecosystems are examples of human-induced disturbance. In such managed systems, non-crop plants (hereafter called weeds) have evolved in response to cropping system practices by adapting and occupying open niches (Dekker 1997). These species are pioneers that increase diversity of agricultural ecosystems by using their environmental potential (Bhowmik 1997) and sometimes may reduce the diversity by pushing the ecosystem towards a mono-dominant structure. Yadav and Gupta (2005) found that the diversity and basal area of most woody species declined with increased human disturbance leading to their complete eradication from highly disturbed forests. The study also showed that species such as Anogeissus pendula exhibited high density in highly disturbed areas, which was in line with Hobbs and Humphries (1995) who noted that the effect of disturbance is influenced by its size and frequency. However, in the Okavango Delta, it has not been established how soil tillage influenced species composition and diversity where molapo farming is practised. Hence, it was imperative to carry out this study to establish how the frequency of disturbance in terms of soil tillage impacts on weed species communities.

While disturbance is widely recognised as a primary influence on plant community in agro-ecosystems, weed species diversity and composition may be influenced by a suite of factors with varying degrees of intensity. These factors include agricultural practices such as weeding, soil tillage and agro-chemicals (Pal et al. 2013; Armengot et al. 2011). Soil tillage has the potential to change the plant community composition and diversity. The frequency of cultivating the land influences changes in weed species richness and diversity (Shemdoe et al. 2008). Soil tillage promotes establishment of highly competitive plant species. It makes soil suitable for germination and seedling establishment (Handa et al. 2012). In minimum till systems, weed seeds accumulate on the soil surface where conditions are favourable for seed germination and thus have high species richness and diversity (Yenish et al. 1992; Shemdoe et al. 2008). Broadleaf weed species tend to dominate under conventional tillage systems and are thought to be stimulated by light as they are brought to the soil surface (Froud-Williams et al. 1983). A study by Yenish et al. (1992) showed that non-tillage systems typically have higher populations of small-seeded annual weeds such as Setaria spp. and Amaranthus spp. while tillage systems using mouldboard ploughs have more largeseeded annual weeds like Xanthium strumarium L. However, studies by Swanton et al. (1999) concluded that there was no consistent relationship between weed diversity and tillage system. This contradictory observation suggests that there may be other factors other than tillage that may influence weed density. Such factors include crop rotation (Swanton and Weise 1991; Andersson and Milberg 1998; Legere and Samson 1999) and cover crops which may have demonstrated allelopathic properties that inhibited weed establishment and growth (Putnam et al. 1983; Mohler and Teasdale 1993). These cover crops have also been found to suppress weeds by competing for water, light and nutrients (Barnes and Putnam 1983). However, there has not been adequate information available on these factors on how they influence weed species composition and diversity in the agro-ecosystems of the seasonal floodplains in the Okavango Delta.

Thus, changes in land use and management practices can influence vegetation composition, especially weed flora in agro-ecosystems. Early studies by Kellman (1980) on geographic patterning in tropical weed communities and early secondary successions found that changing from shifting to intensive or permanent agriculture in the tropics eliminated many woody species and replaced them with aggressive herbaceous weed species. In flood recession farming, plant species composition can be influenced by desiccation and/or reduced flooding. Handa et al. (2012) showed that facultative upland weeds completely dominated the drained cultivated sites as opposed to permanently inundated areas dominated by either obligate or facultative wetland species. Similarly, in the Okavango Delta, Setaria sphacelata was found to be more pronounced in areas subjected to shallow flooding (Bonyongo 1999) while Eleocharis dulcis and Leersia hexandra were found to be facultative wetland species as they were more tolerant to prolonged flooding (Tsheboeng et al. 2014). These studies were focused on the floodplains, and no vegetation studies to date have been done in molapo farming. Molapo farming includes intensive cultivation of the floodplains (Oosterbaan et al. 1987; Petermann 1989; Bendsen 2002; Mmopelwa 2011). It is practised along the edges of the river channels or seasonally flooded depressions on the fringes of the Okavango Delta (Bendsen 2002). Given that this farming system is an essential livelihood activity for the majority of the communities that reside along the Okavango Delta, it warrants that similar studies should also be conducted in molapo farming. Therefore, this study was conducted to determine the influence of cultivation frequency on weed species composition and diversity in flood recession farming in the Okavango Delta. 


\section{Methods}

\section{Description of the study area}

The study was conducted in the villages of Shorobe, Makalamabedi and Lake Ngami (Fig. 1). The sites were chosen for their contrasting hydrology in terms of flooding patterns and the location of molapo fields. Shorobe is located in the eastern end of the Okavango Delta, and its administrative boundary is $1078 \mathrm{~km}^{2}$ and lies $30 \mathrm{~km}$ east of Maun in Ngamiland District. It has a human population of 1031 (Statistics Botswana 2011). Molapo fields are located in the northwest of the village and are inundated by the Santantadibe and Gomoti Rivers and by backflow from the Thamalakane River. The molapo fields in Shorobe are mainly found in islands with dense riparian woodlands, and they have a saucer-shaped cross-section and obtain moisture from spillover or backflow water from the main river channels (Bendsen 2002). Normally, this area experiences maximum flood extent between August and September, and by the end of October, the flood begins to recede. Lake Ngami occupies the northeast part of a shallow sedimentary basin bounded to the

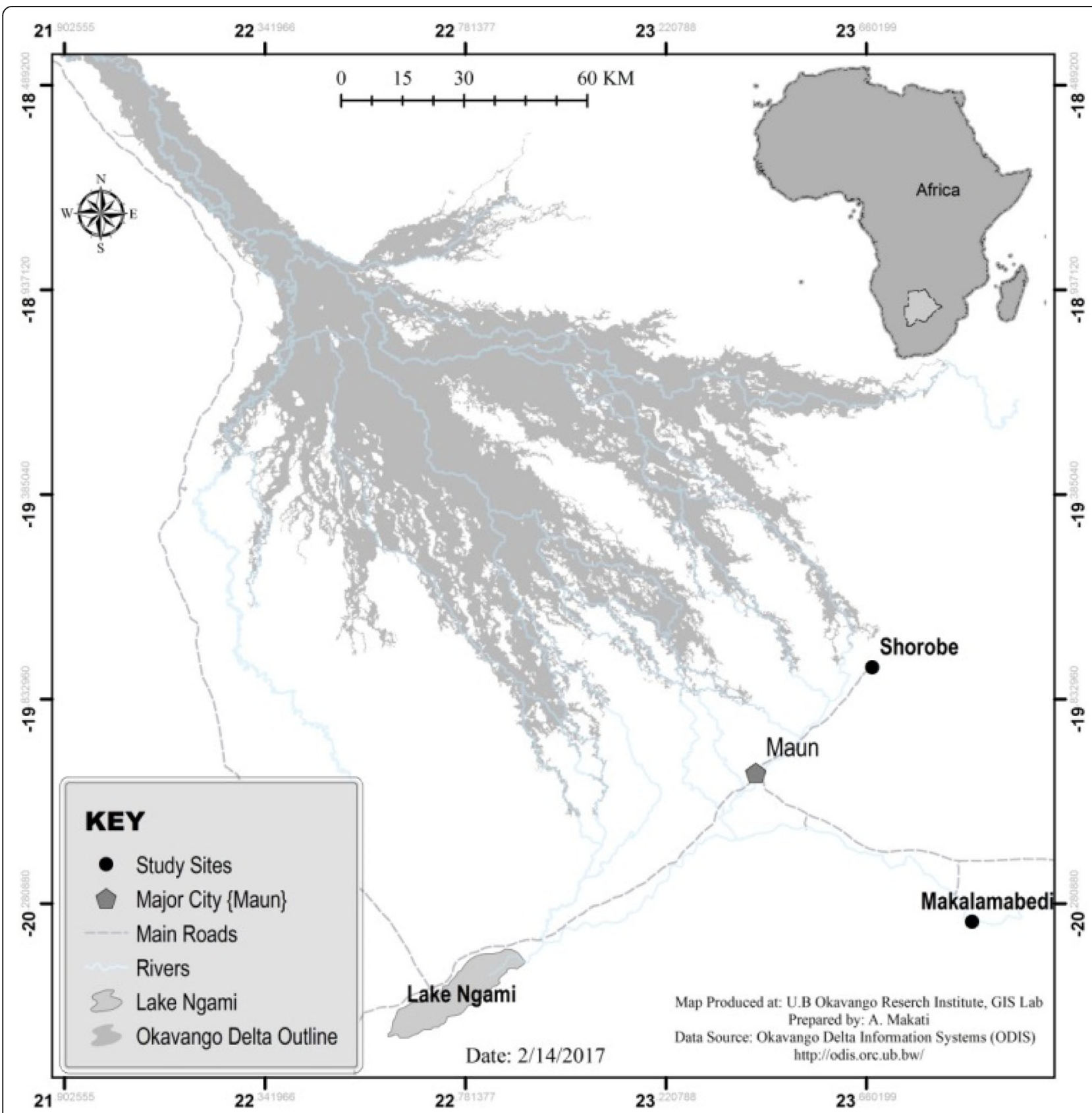

Fig. 1 The Okavango Delta area, showing the study sites of Shorobe, Makalamabedi and Lake Ngami 
southeast by a low escarpment of Karoo and Ghanzi Formation rocks along an extension of the Kunyere Fault (Reeves 1978). Lake Ngami did not receive enough flood water between 1989 and 2004. And farmers did not cultivate their molapo fields during these dry periods (Mmopelwa 2011). As a result, most molapo fields are relatively new and not permanently placed like those at Shorobe and Makalamabedi. The maximum flood extent is usually experienced on average in October. The lake is surrounded by Toteng, Sehithwa, Bodibeng and Bothatogo villages. At the last census, the human population for these villages was 902, 2748, 778 and 555 respectively (Statistics Botswana 2011). Lastly, Makalamabedi lies $83 \mathrm{~km}$ southeast of Maun along the Boteti River. The veterinary cordon fence that cuts through the village divides the village into two districts. Makalamabedi on the western side of the cordon fence lies on the Ngamiland District with a population of 1010 while the eastern side of the fence lies on the Central district with 1674 people (Statistics Botswana 2011). Arable farming is done in fields allocated along the Boteti River. Molapo fields located on steep banks along the Boteti River are characterised as channel type (Bendsen 2002). This river is an ephemeral water channel which derives flood waters from the Okavango Delta through Thamalakane River. It flows in a south-easterly direction and finally discharges into Lake Xau. The peak floods are between August and September.

\section{Selection of study sites (molapo fields)}

Field visits were conducted to identify molapo fields at the different study sites. Once suitable fields had been identified, consent was sought from farmers and information gathered on tillage history in terms of the number of years the field has been cultivated. The fields were categorised according to the historic frequency of continuous cultivation in years. The categories were defined as follows: continuous cultivation for the previous 5 years, 10 years and 15 years, while equivalent sites with no history of cultivation were used as a control. Simple random sampling (SRS) was then carried out using a random number generator in MS Excel to draw 3 fields from each stratum or cultivation frequency. A total of 12 fields per study site were selected (Fig. 2).

\section{Vegetation sampling}

Vegetation was surveyed at the three sites from March to the end of April 2016, when most plants were flowering for easy identification. Since fields have a small hectarage, a 50-m line transect was used in each field. The line transects were laid parallel to each other and spaced $20 \mathrm{~m}$ apart. Weed species composition and abundance were then recorded in $1-\mathrm{m}^{2}$ quadrats placed along each transect at a 10-m interval. Since molapo fields have small hectarage and irregular shape, the number of quadrats surveyed differed from one site to the other. For instance, a total of 93 quadrats were surveyed at Shorobe, 86 at Makalamabedi and 74 at Lake Ngami. In each quadrat, all species were identified and the number of individuals was counted (without accounting for vegetative reproduction). Unidentified plants were mounted and taken to the Peter Smith University of Botswana (PSUB) herbarium at the Okavango Research Institute for identification.

\section{Data analysis}

Agglomerative hierarchical cluster analysis was used to group species. It was performed using Sorensen distance measure with flexible beta linkage; $\beta=-0.25$ in PC-ORD 6 software (McCune and Mefford 2011). This was done by clustering groups of species based on the number of times they occur with each other in the field quadrat data. Indicator Species Analysis (Dufrene and Legendre 1997) was used to calculate indicator values for species in groups determined from cluster analysis. Each group was named using the weed species with the highest indicator value and a significant $p$ value $(p \leq 0.05)$. Multi-response permutation procedure (MRPP) was used in testing the hypothesis of no difference between the groups of species communities in molapo farming using the Sorensen distance measure. The test statistic $T$ was calculated as $T=((\delta \mathrm{ob}-$ served - $\delta$ expected)/s.dev $\delta$ expected). This determines the separation between weed species communities, with more negative values indicating stronger separation. Within-group homogeneity is determined by the effect size or chance-corrected within-group agreement $A=1-(\delta$ observed $/ \delta$ expected $) . A=1$ when all items are identical within groups $(\delta=0), A=0$ when heterogeneity within groups equals expectation by chance and $A<0$ with more heterogeneity within groups than expected by chance.

Species diversity and evenness were determined for each frequency of cultivation within and across the study sites. Shannon's diversity indices were determined using Paleontological Statistics (PAST) version 3.12. Kruskal-Wallis was used to test for statistically significant differences in species density across the cultivation frequencies as well as species diversity between frequency of cultivation within and across the study sites. Since Kruskal-Wallis is an omnibus test, independentsample median test was conducted to establish which groups differ significantly (between-group comparisons). This was performed in SPSS version 24. Rank/ abundance plot was used to plot species abundance data to rank weed species for each cultivation frequency. The species abundances were displayed in $\log _{10}$ format to accommodate species whose abundances span several orders of magnitude on the same graph 


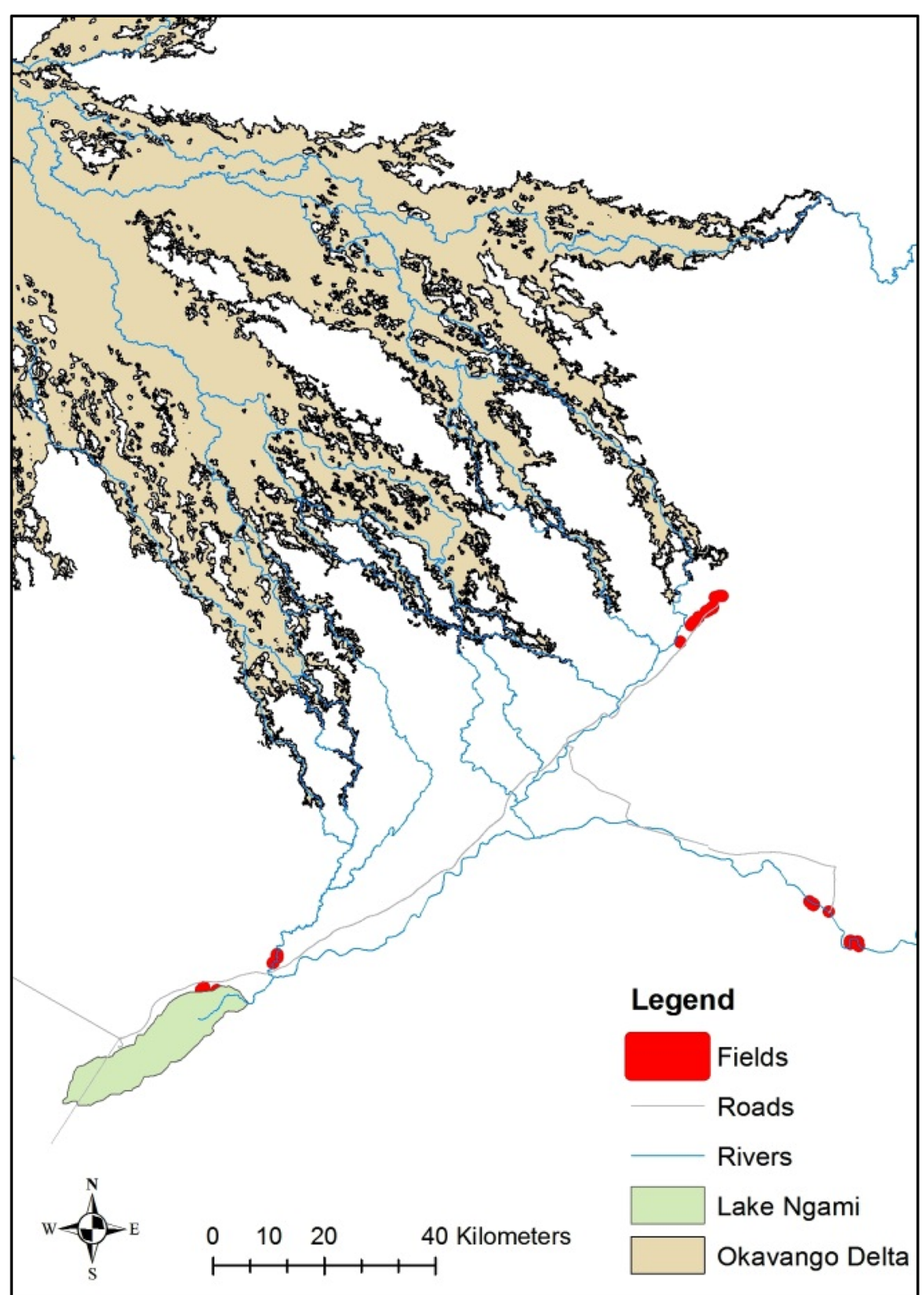

Fig. 2 The distribution of sampled molapo fields at Shorobe, Makalamabedi and Lake Ngami

(Magurran 2004). This assisted in determining the association between weeds and the cultivation frequencies, and it was performed in PC-ORD 6.

\section{Results}

Determination of number of clusters and Indicator Species Analysis

The number of weed species clusters/communities was determined at four divisions where the mean $p$ value $(p<0.05)$ was minimised (Fig. 3). The main weedy species communities identified were Cynodon dactylonBulbostylis hispidula, Sida cordifolia-Corchorus tridens, Glinus oppositifolius-Heliotropium ovalifolium and Sida alba-Abutilon angulatum. Cultivation frequency did not significantly influence weed species density $(p>0.05)$ across the study sites (Fig. 4). Furthermore, there was a stronger separation between Cynodon dactylon-Bulbostylis hispidula and Sida cordifolia-Corchorus tridens communities, while 


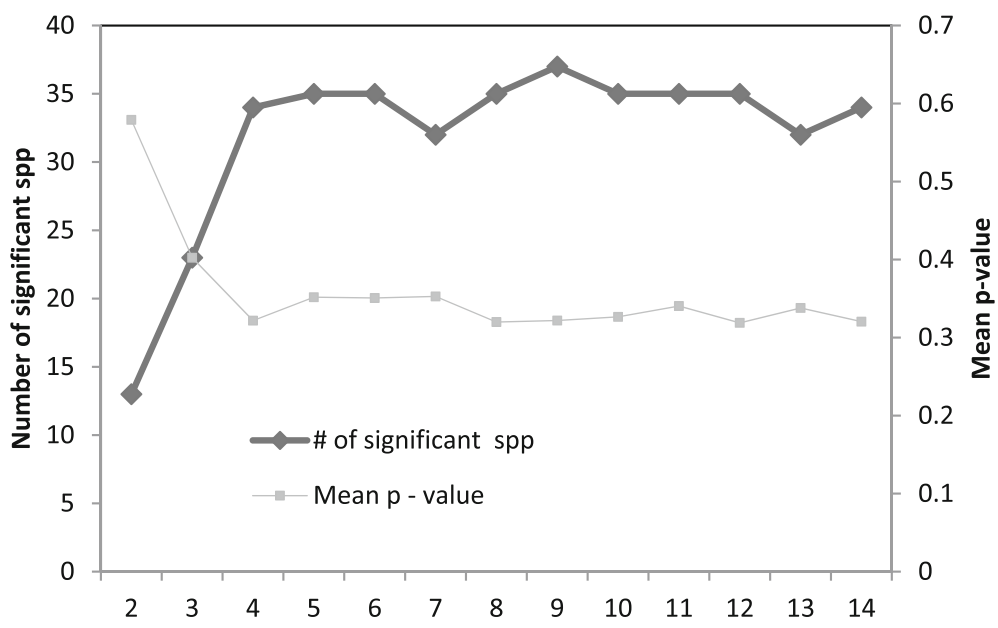

Fig. 3 Determination of number of ecologically meaningful clusters for weedy species classification

Sida cordifolia-Corchorus tridens and Sida alba-Abutilon angulatum communities were closer together (Table 1 ).

\section{Description of the different weed species communities Cynodon dactylon-Bulbostylis hispidula community}

This community was composed of 30 species and was dominated by Cynodon dactylon (L) Pers and Bulbostylis hispidula (Vahl.). It was also defined by Acanthospermum hispidum DC., Triumfetta pentandra A.Rich, Nidorella resedifolia DC. and Phylla nodiflora (L.). This community is mostly characterised by herbaceous plants and few species from the Poaceae family. It was observed that it occurs mainly in fields that have a 10-year cultivation frequency and fields situated mainly on the upper slopes or upper zones of the flood zones.

Sida cordifolia-Corchorus tridens weed species community This community recorded a total of 28 species, dominated by Sida cordifolia L. and Corchorus tridens L. It was also represented by Ipomea sinensis (Desr.), Digitaria debilis (Desf.), Ipomoea coptica (L.) Roem. \& Schult. and Hibiscus cannabinus L. Some species in this community are reported to be mostly dominant in fields with a 15-year cultivation frequency like Corchorus tridens L., Ipomea sinensis (Desr.) and Panicum coloratum L.

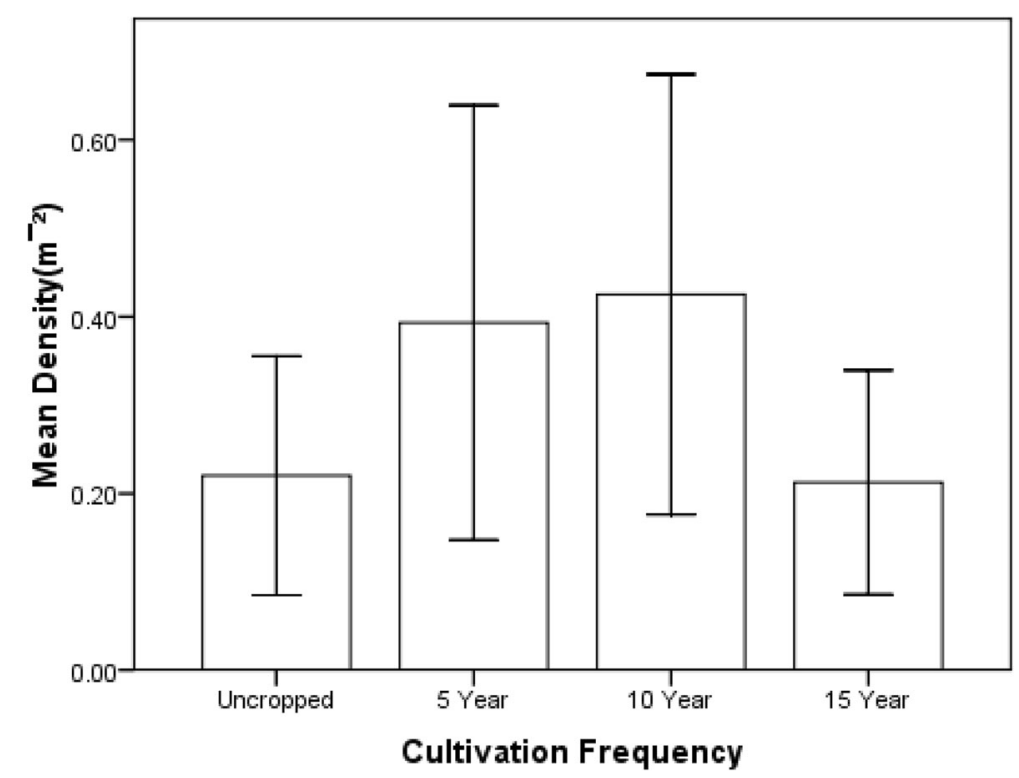

Fig. 4 Mean species density across the cultivation frequencies. There was no significant difference $(p>0.05)$ 
Table 1 A multi-response permutation procedure (MRPP) pairwise comparison for the species communities.

\begin{tabular}{llll}
\hline Groups compared & $T$ & $A$ & $p$ \\
\hline Cyndac-Bulhis vs. Sidcor-Cortri & -38.6297913 & 0.071374 & 0.001 \\
Cyndac-Bulhis vs. Gliopp-Helova & -34.7072352 & 0.0659926 & 0.001 \\
Cyndac-Bulhis vs. Sidalb-Abiang & -20.8766535 & 0.0887329 & 0.001 \\
Sidcor-Cortri vs. Gliopp-Helova & -35.3593382 & 0.0470391 & 0.001 \\
Sidcor-Cortri vs. Sidalb-Abiang & -19.6246419 & 0.0481293 & 0.001 \\
Gliopp-Helova vs. Sidalb-Abiang & -20.4255302 & 0.0505249 & 0.001
\end{tabular}

Cyndac-Bulhis, Cynodon dactylon-Bulbostylis hispidula; Sidcor-Cortri, Sida cordifolia-Corchorus tridens; Sidalb-Abiang, Sida alba-Abutilon angulatum; and Gliopp-Helova, Glinus oppositifolius-Heliotropium ovalifolium

\section{Glinus oppositifolius-Heliotropium ovalifolium weed species community}

A total of 29 species were identified in this community. It was dominated by Glinus oppositifolius (L.) Aug.DC. and Heliotropium ovalifolium Forssk. This community was also characterised by Cyperus esculentus L., Fimbristylis dichotoma (L.) Vahl, Cyperus latifolius Poir., Pavonia senegalensis Cav. and Alternanthera sessilis (L.) DC. These species are tolerant to high moisture content. It was observed that this community occurs mainly in uncropped fields which normally get inundated during flooding.

\section{Sida alba-Abutilon angulatum weed species community}

This community was constituted by 15 species, dominated by Sida alba L. and Abutilon angulatum (Guill\&Perr)
Mast. Other species defining this community were Xanthium strumarium L., Chenopodia carinatum R.Br., Eclipta prostrata (L.) and Chamaecrista biensis (Steyaert) Lock. This community was observed to inhabit fields with a cultivation frequency of 5 years, mostly fields situated within the lower gradient of the floodplains.

\section{Species diversity within study sites \\ Lake Ngami}

Lake Ngami did not have both 10- and 15-year cultivation frequencies. Uncropped sites had the highest Shannon's diversity index of 1.22 compared with 1.11 recorded at the 5 -year cultivation frequency, but the difference was not statistically significant (Fig. 5), suggesting that cultivation frequency did not have an effect on weed species diversity at Lake Ngami. Similarly, the species evenness was similar across the cultivation frequency $(p>0.05)$, indicating that cultivation frequency did not have an effect on species evenness (Fig. 6).

\section{Makalamabedi}

Uncropped and 5-year cultivation frequency had similar species diversity and were both higher than the 10and 15-year cultivation frequency (Fig. 5). However, the 5-year cultivation frequency displayed significantly higher mean species diversity than both the 10-year and 15-year cultivation frequencies at $p<0.05$. This showed a descending trend as the frequency of cultivation increased. However, uncropped sites showed a

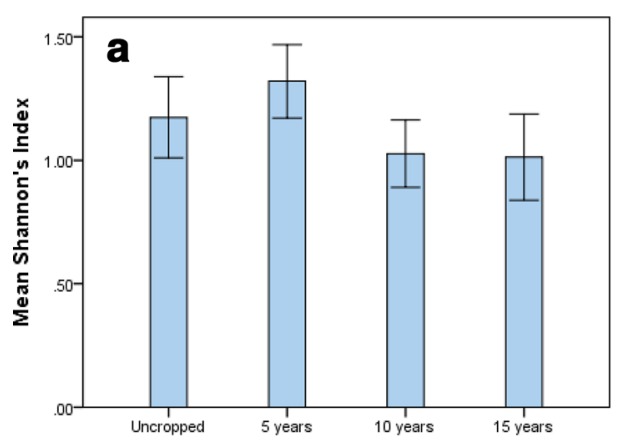

Cultivation Frequency - Makalamabedi

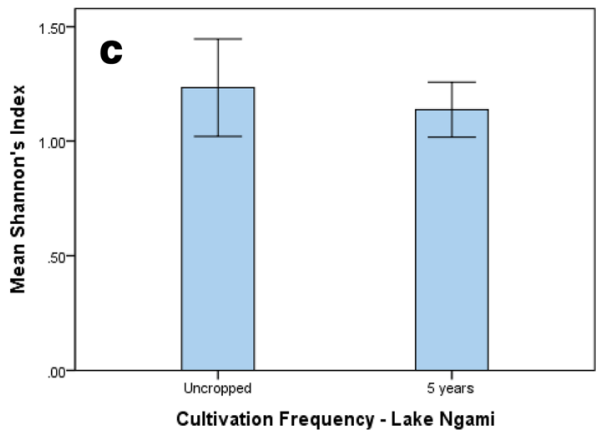

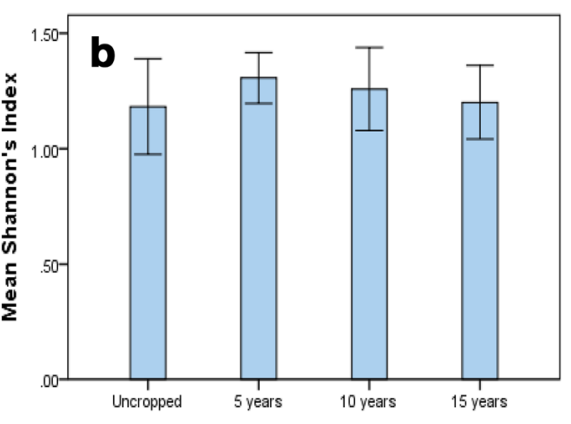

Cultivation Frequency - Shorobe 

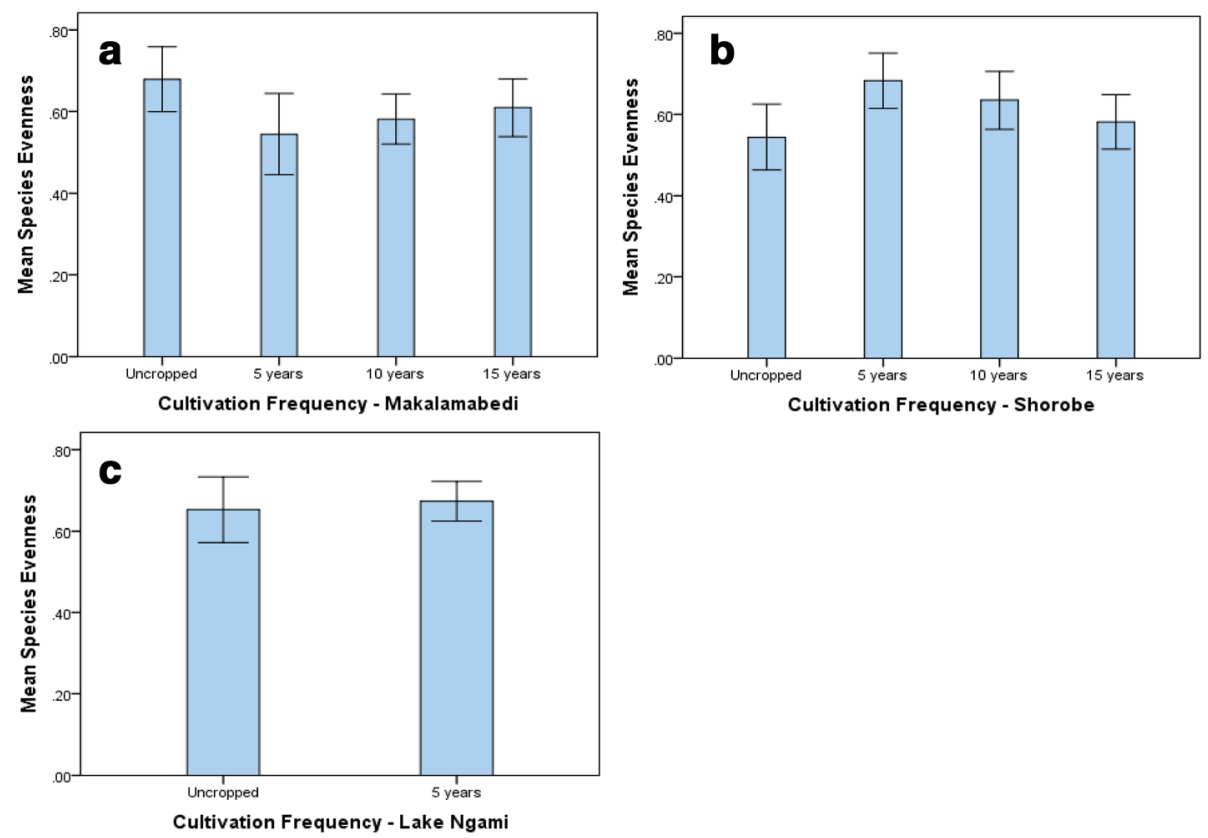

Fig. 6 Influence of cultivation frequency on species evenness within the study sites (a Makalamabedi, b Shorobe, c Lake Ngami)

high presence of species than both the 10- and 15-year cultivation frequencies, but the difference was not significant $(p>0.05)$. There was no significant difference $(p>0.05)$ in mean species evenness across the cultivation frequencies, suggesting that Shannon's equitability index (species evenness) was not influenced by the frequency of cultivation at Makalamabedi (Fig. 6).

\section{Shorobe}

The 5-year cultivation frequency displayed higher species diversity and evenness than the 10-year and 15-year cultivation frequencies (Fig. 5). However, this trend was not statistically significant $(p>0.05)$. On the other hand, mean species evenness was significant across the cultivation frequencies $(p<0.05)$. The results suggested that cultivation frequency influenced weed species evenness in Shorobe. Further investigation suggested that 5-year cultivation frequency $(M=0.653, \mathrm{SD}=0.171)$ differed significantly with uncropped fields $(M=0.544, \mathrm{SD}=$ 0.198). This indicated that species present at the 5-year cultivation frequency are distributed equitably than in the uncropped fields (Fig. 6).

\section{Species diversity indices across the study sites as defined by the different cultivation frequencies}

Kruskal-Wallis test was used to test for statistically significant difference in mean species evenness and species diversity between cultivation frequencies. There was a statistically significant difference in mean species diversity $\left(\mathrm{H}^{\prime}\right)$ across the four cultivation frequencies ((uncropped, $n=38$; 5 years, $n=43 ; 10$ years, $n=51 ; 15$ years, $n=47$ ), $\chi^{2}(3, n=179)=8.217, p=0.042$ (Fig. 7)). The 5-year cultivation frequency recorded a higher median score $(\mathrm{Md}=1.352)$ than the other cultivation frequencies while 15-year cultivation frequency recorded the lower median score $(M d=1.035)$ than the other categories. There was no statistically significant difference in mean species evenness across the cultivation frequencies ((uncropped, $n=38$; 5 years, $n=43 ; 10$ years, $n=51 ; 15$ years, $n=47$ ), $\chi^{2}(3, n=179)=1.107, p=0.775$ (Fig. 8)). The results suggested that the equitable distribution of weed species was similar across the cultivation frequencies.

The association of weed species with the cultivation frequencies is presented in Table 2. Cyperus esculentus L., Corchorus tridens L. and Cynodon dactylon (L.) Pers. were the most abundant in uncropped sites, 5-, 10 - and 15-year frequencies, respectively. Corchorus tridens L. was found in all the frequencies except in uncropped. The uncropped fields have mostly species from the Cyperaceae family. Digitaria debilis (Desf.) is the only species from the Poaceae that forms part of the five most abundant species in uncropped fields.

\section{Discussion}

Previous studies in the Okavango Delta such as Tsheboeng et al. (2014), Murray-Hudson et al. (2006), McCarthy et al. (2005), Bonyongo (1999) and Ellery et al. (1993) have demonstrated that vegetation communities are influenced by flood duration, depth and frequency. In flood recession farming areas of the Okavango Delta, weed species composition and diversity were found to be influenced by frequency of cultivation, suggesting that cultivation 


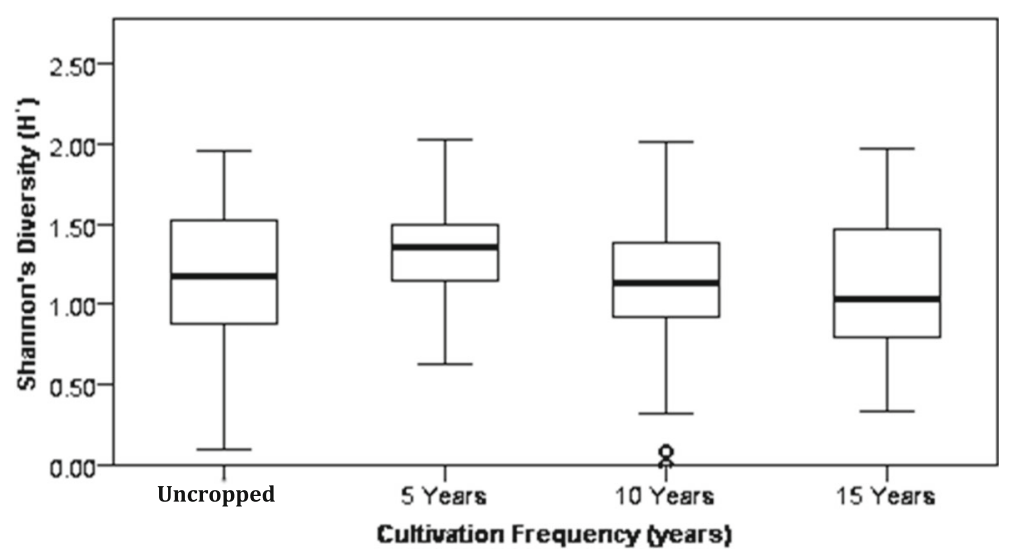

Fig. 7 Graphical representation of the independent-samples Kruskal-Wallis test on Shannon's diversity index across the study sites

frequency can be an important driver of weed species assemblages in flood recession farming. Species diversity decreased with increasing frequency of cultivation while species evenness was not affected. This was probably due to cultivation over the years that might have stimulated germination of weed seeds from the seed bank resulting in a decrease in the seed bank especially when there is no seed rain to replenish the seed bank. In support of this assertion, Froud-Williams et al. (1983) stated that nondominant buried seeds will be brought to the soil surface and germinate upon cultivation.

High species diversity in fields categorised under the 5 -year frequency might be due to availability of seed bank that has been buried. Consequently, fields in this cultivation frequency are relatively new, and as such, they harbour more seed banks which might have led to high species diversity than the other cultivation frequencies. On the other hand, fields under the 15-year cultivation frequency are older fields that have been subjected to intense cultivation for a long period of time. This could have led to reduction in the size of the seed bank resulting in low weed density and consequently low diversity. Similarly, Streibig (1988) pointed out that recurring soil preparation techniques impose strong selection pressure upon weed flora. On the whole, this might explain why the 5 -year cultivation frequency has high weed species diversity than the 15-year cultivation frequency. Comparatively, the 5-year cultivation frequency is a moderate level of disturbance in arable fields; the results could thus support the intermediate disturbance hypothesis (Grime 1973; Connell 1978). Intermediate disturbance hypothesis (IDH) states that species diversity is maximised when disturbance is neither too rare nor too frequent. Similarly, species diversity was maximised at the 5-year cultivation frequency and declined significantly with an increase in cultivation frequency. Uncropped fields also recorded lower species diversity than the 5-year frequency. This could be that at the 5-year cultivation frequency, weed species that thrive at both early and late successional stages can co-exist. In support of this, Huston (1979) mentioned that reduced levels of disturbance will lead to low diversity through competitive exclusion and dominance of long-lived

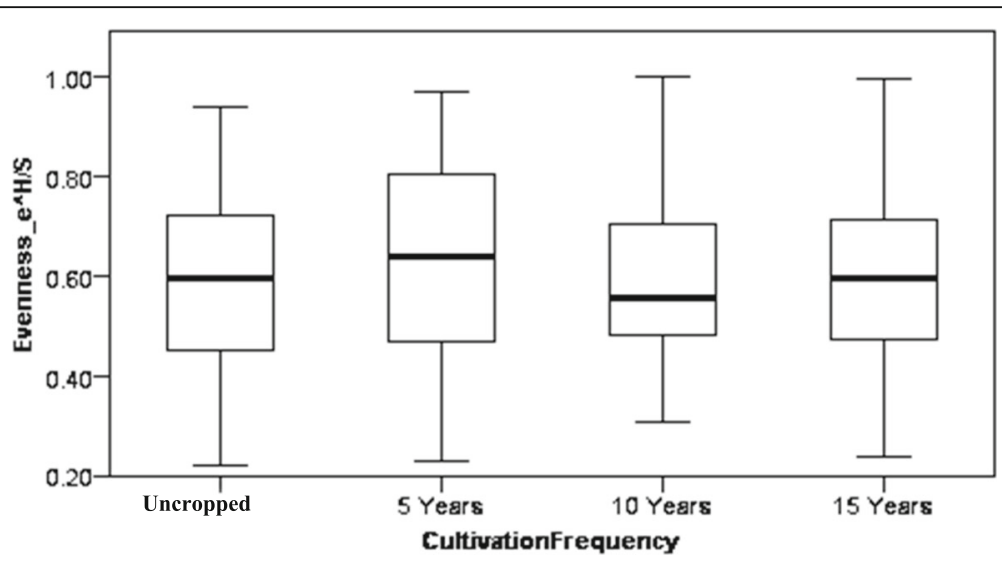

Fig. 8 Graphical representation of the independent-samples Kruskal-Wallis test on species evenness across the study sites 
Table 2 Five most abundant weed species at each cultivation frequency

\begin{tabular}{|c|c|c|c|}
\hline $\begin{array}{l}\text { Cultivation } \\
\text { frequency }\end{array}$ & Species & Family & $\begin{array}{l}\text { Rank of } \\
\text { abundance }\end{array}$ \\
\hline \multirow[t]{5}{*}{ Uncropped } & Cyperus esculentus L. & Cyperaceae & 1 \\
\hline & Cyperus latifolius L. & Cyperaceae & 2 \\
\hline & Digitaria debilis(Desf.) & Poaceae & 3 \\
\hline & $\begin{array}{l}\text { Fimbristylis dichotoma } \\
\text { (L.) Vahl }\end{array}$ & Cyperaceae & 4 \\
\hline & Cyperus longus L. & Cyperaceae & 5 \\
\hline \multirow[t]{5}{*}{5 years } & Corchorus tridens L. & Tiliaceae & 1 \\
\hline & $\begin{array}{l}\text { Cynodon dactylon } \\
\text { (L.) Pers. }\end{array}$ & Poaceae & 2 \\
\hline & $\begin{array}{l}\text { Bulbostylis hispidula } \\
\text { (Vahl) R.W.Haines }\end{array}$ & Cyperaceae & 3 \\
\hline & Ipomea sinensis (Desr) & Convolvulaceae & 4 \\
\hline & $\begin{array}{l}\text { Heliotropium ovalifolium } \\
\text { Forssk. }\end{array}$ & Boraginaceae & 5 \\
\hline \multirow[t]{5}{*}{10 years } & Cynodon dactylon (L.)Pers. & Poaceae & 1 \\
\hline & Corchorus tridens L. & Tiliaceae & 2 \\
\hline & $\begin{array}{l}\text { Acanthospermum } \\
\text { hispidum DC. }\end{array}$ & Asteraceae & 3 \\
\hline & Sida cordifolia L. & Malvaceae & 4 \\
\hline & $\begin{array}{l}\text { Triumfetta pentendra } \\
\text { A.Rich }\end{array}$ & Malvaceae & 5 \\
\hline \multirow[t]{5}{*}{15 years } & Corchorus tridens L. & Tiliaceae & 1 \\
\hline & Ipomea sinensis (Desr.) & Convolvulaceae & 2 \\
\hline & Panicum coloratum L. & Poaceae & 3 \\
\hline & $\begin{array}{l}\text { Bulbostylis hispidula } \\
\text { (Vahl) R.W.Haines }\end{array}$ & Cyperaceae & 4 \\
\hline & Cyperus articulatus L. & Cyperaceae & 5 \\
\hline
\end{tabular}

species while increased levels eliminate species incapable of rapid re-colonisation and growth. In summary, in arable fields, reduced levels of disturbance could be through fallowing.

The influence of cultivation frequency on weed species abundance was determined by rank/abundance plots. Five common weed species were selected at each cultivation frequency as also demonstrated by Shemdoe et al. (2008). The uncropped sites were mostly dominated by species belonging to the Cyperaceae family, and Cyperus esculentus L. was the most frequently occurring species. Other species that occurred more frequently in the uncropped sites were Cyperus latifolius L., Fimbristylis dichotoma (L.)Vahl and Cyperus longus $\mathrm{L}$. In a similar study in the Okavango Delta, Bonyongo (1999) recorded Cyperus species in floodplain vegetation. The study also linked the observed different plant communities to differences in flooding time and duration. Murray-Hudson et al. (2006) also noted that Cyperus species are wetland species that are able to tolerate some dry periods and as such are found in areas that are flooded on seasonal basis such as molapo farming. Most species found in uncropped sites had rhizomes on which tubers develop and lie dormant in the soil for a longer period of time. This might explain their coexistence and dominancy in uncropped sites. Additionally, Digitaria debilis (Desf.) was the only species of the Poaceae family most dominant in uncropped sites. It shared a similar habitat with the species of the Cyperaceae which were mostly abundant in uncropped fields. According to Heath and Heath (2009), D. debilis (Desf.) occasionally colonises damp areas of the flood plains and often rooted in water. However, the absence of these species at both the 5- and 10-year cultivation frequencies might be due to the fact that tillage reduces regenerative potential of perennial weeds (Stoller and Sweet 1987) because the tubers are sensitive to cultivation. Previous studies by Bangarwa et al. (2012) and Stoller et al. (1972) indicated that tubers for species like Cyperus esculentus L are equally sensitive to soil disturbance despite the number of times the disturbance is repeated.

Consequently, all the three cultivation frequencies were dominated by common arable weed species such as C. tridens L., C. dactylon, Ipomea species and Acanthospermum hispidum DC. In addition, Corchorus species are common weeds in Europe, Australia, Asia and Africa (Holm et al. 1979). It is the only species that appeared across all the frequencies except in uncropped fields. According to Dzerefos et al. (1995), C. tridens $\mathrm{L}$ has affinity to cultivated land, and it is also one of the weeds that are commonly used as traditional vegetables, especially in Africa (Maroyi et al. 2013). In Botswana, Corchorus species are mostly found around the Okavango Delta (Phillips 1991) while $C$. dactylon is widespread in Botswana as a weed in both dry land and irrigated fields (Abdullahi 2002). Similarly, Acanthospermum hispidum is a troublesome weed in agricultural fields and is one of the top 10 common weeds in the USA (Teuton et al. 2006). Equally, in Botswana, it is found in cultivated fields and other disturbed places where it forms dense stands (Abdullahi 2006).

The species that are more frequently occurring at the 5-year cultivation frequency were $C$. tridens, $C$. dactylon, B. hispidula, Ipomea sinensis and Heliotropium ovalifolium. Moreover, Cynodon dactylon was mostly abundant in the 5 -year and 10-year cultivation frequencies. It was however observed that most fields at the 15-year cultivation frequency had no visibility of Cynodon dactylon across the study sites. In view of this, it could be suggested that as the intensity of cultivation increases, the abundance of $C$. dactylon also decreases. Since this weed species is rhizomatous (Labovitch 1978), the frequency of cultivation might 
have interfered with its vegetative reproduction by disturbing the development of the rhizomes leading to a reduction in its abundance from the 10- to 15-year cultivation frequencies.

\section{Conclusions}

This study has demonstrated that cultivation frequency influenced weed species composition and diversity in flood recession farming areas of the Okavango Delta. Frequently cultivated molapo fields were dominated by weed species. Uncropped sites were composed of wetland species that tolerate some dry periods or seasonal flood plains. Findings from this study contribute towards development of weed management strategies in flood recession farming.

\section{Acknowledgements}

The authors would like to thank Mrs. A. Makati and Mr. K. Sianga for designing the maps used. Appreciation is extended to Dr. G. Tsheboeng for the suggestions and comments he made in this work and University of Botswana staff at the Peter Smith Herbarium for assisting with identifying weed species collected from the field.

\section{Funding}

Gratitude is extended to the University of Botswana (Office of Research and Development) for funding this project.

\section{Availability of data and materials}

Contact the author for data requests.

\section{Authors' contributions}

MN initiated, conceptualised and designed the structure of this manuscript. He collected the data and analysed and drafted the write-up of the manuscript. KK revised the structure and reviewed and added more information to the draft manuscript. MMH critically reviewed the different sections of the manuscript. All authors read and approved the final manuscript.

Ethics approval and consent to participate

Not applicable

\section{Consent for publication}

Not applicable

\section{Competing interests}

The authors declare that they have no competing interests.

\section{Publisher's Note}

Springer Nature remains neutral with regard to jurisdictional claims in published maps and institutional affiliations.

Received: 25 May 2018 Accepted: 7 September 2018

Published online: 27 September 2018

\section{References}

Abdullahi AE (2002) Cynodon dactylon control with tillage and glyphosate. Crop Prot 21(10):1093-1100

Abdullahi, AE (2006) Field Guide to Weeds of Botswana. Printing and Publishing Co, ISBN 99912-0-62-5. Gaborone. pp. 124

Andersson TN, Milberg P (1998) Weed flora and the relative importance of site, crop, crop rotation, and nitrogen. Weed Sci 46:30-38

Armengot L, Jose'-Maria L, Blanco-Moreno JM, Romaro-Puente A, Xavier Sans F (2011) Landscape and land use effects on weeds flora in Mediterranean cereal fields. Agric Ecosyst Environ 142(2011):311-317

Bangarwa SK, Norsworthy Jk, Gbur EE (2012) The effect of shoot clipping - soil disturbance frequency and tuber size on above ground and below ground growth of purple and yellow nutsedge (Cyperus rotundus) and Cyperus esculentus. Weed Technol 26(4):813-817

Barnes JP, Putnam AR (1983) Rye residues contribute weed suppression in notillage cropping systems. J Chem Ecol 9(8):1045-1057

Bendsen HMT (2002) The Dynamics of Land Use System in Ngamiland; Changing Livelihood Options and Strategies. Harry Oppenheimer Okavango Research Centre and German Development Service - DED, Maun, Botswana

Bhowmik PC (1997) Weed biology: importance to weed management. Weed Sci 45(3):349-356

Bonyongo C (1999) Vegetation ecology of the seasonal floodplains in the Okavango Delta, Botswana. MSc Thesis, University of Pretoria, Pretoria. http:// hdl.handle.net/2263/22903

Connell JH (1979) Intermediate-Disturbance Hypothesis. Science 204(4399):1345. https://doi.org/10.1126/science.204.4399.1345

Dekker J (1997) Weed diversity and weed management. Weed Sci 45(3):357-363

Dufrene M, Legendre P (1997) Species assemblages and indicator species: the need for a flexible asymmetrical approach. Ecol Monogr 61:53-73

Dzerefos CM, Shackleton CM, Scholes MC (1995) Econ Bot 49:380 https://doi.org/ 10.1007/BF02863088

Ellery WN, Ellery K, McCarthy TS (1993) Plant distribution in islands of the Okavango Delta, Botswana: determinants and feedback interactions. Afr J Ecol 31(2):118-134

Froud-Williams RJ, Drennan DSH, Chancellor RJ (1983) Influence of cultivation regime on weeds floras of arable cropping systems. J Appl Ecol 20(1):187-197. https://doi.org/10.2307/2403385

Grime JP (1973) Competitive exclusion in herbaceous vegetation. Nature 242: $344-347$

Handa C, Alvarez M, Becker M, Oyieke H, Moseler BM, Mogha N, Kamiri H (2012) Opportunistic vascular plant introductions in agricultural wetlands of East Africa. Int J Agric Sci Vol 2(9):810-830

Heath A, Heath R (2009) Field Guide to the Plants of Northern Botswana including the Okavango Delta. Kew Publishing, Royal Botanic Gardens, Kew, p 594

Hobbs RJ, Humphries SE (1995) An integrated approach to the ecology and management of plant invasions. Conserv Biol 9(4):761-770

Holm L, Pancho JV, Herberger JP, Plucknett DL (1979) A geographical atlas of world weeds. Wiley, New York, p 391

Huston M (1979) A General Hypothesis of Species Diversity. The American Naturalist 113(1):81-101

Kellman M (1980) Geographic patterning in tropical weed communities and early secondary successions. Biotropica 12(2):34-39

Labovitch L (1978) Traditional and new methods of dealing with arable weeds in Botswana. Botswana Notes Rec 10(1978):187-197

Legere A, Samson N (1999) Relative influence of crop rotation, tillage, and weed management on weed associations in spring barley cropping systems. Weed Sci 47:112-122

Magurran A (2004) Measuring Biological Diversity. Blackwell Publishing, Oxford RU ISBN: 0-632-05633-9

Maroyi A (2013) Use of weeds as traditional vegetables in Shurugwi District, Zimbabwe. J Ethnobiol Ethnomed 9(1):60-69

McCarthy J, Gumbricht T, McCarthy TS (2005) Ecoregion classification in the Okavango Delta, Botswana from multitemporal remote sensing. Int J Remote Sens 26(19):4339-4357

McCune B, Mefford MJ (2011) PC-ORD. Multivariate analysis of ecological data. Version 6. MjM Software, Gleneden Beach, Oregon

Mmopelwa G, Vanderpost C, Wolski P, Kgathi DL (2011) The impact of environmental change on ecosysterm services supporting human livelihoods: the case of the Okavango and Boteti basins, Botswana. Report of the SysTems for Analysis Research and Training (START), Washington DC, USA.

Mohler CL, Teasdale JR (1993) Response of weed emergence to rate of Vicia villosa Roth. and Secale cereale L. residue. Weed Res 33:487-499

Murray-Hudson M, Wolski P, Ringrose S (2006) Scenarios of the impact of local and upstream changes in climate and water use on hydro-ecology in the Okavango Delta, Botswana. J Hydrol. 331(1-2):73-84

Oosterbaan RJ, Kortenhorst LF, Sprey LH (1987) Development of flood-recession cropping in the molapos of the Okavango Delta, Botswana. Annual Report 1986. International Institute for Land Reclamation and Improvement, Wageningen, Published by Gower; IAAE, Occasional Paper 4:8-29.

Pal RW, Pinke G, Botta-Dukát Z, Campetella G, Bartha S, Kalocsai R, Lengyel A (2013) Can management intensity be more important than environmental 
factors? A case study along an extreme elevation gradient from central Italian cereal fields. Plant Biosyst 147(2):343-353

Petermann K, Sabure (1989) Distribution of molapo farming areas in BoroShorobe flood plains. Ministry of Agriculture, Gaborone, Botswana

Phillips M (1991) A guide to the arable weeds of Botswana. Ministry of Agriculture, Botswana

Powell DC (2000) Potential vegetation, disturbance, plant succession and other aspects of forest ecology. US Department of Agriculture, Forest Service, Pacific Northwest Region, Umatilla National Forest, Tech Pub F14-SO-TP-09-00, p 10

Putnam AR, DeFrank J, Barnes JP (1983) Exploitation of alle-lopathy for weed control in annual and perennial cropping systems. J Chem Ecol 9:1001-1010

Reeves CV (1978) The gravity survey of Ngamiland, 1970-71.Director, Geological Survey Department, Lobatse, Botswana.

Shemdoe, RS., Mbago, FM., Kikula, S., and Van Damme, PL. (2008). Weeds species diversity on arable land of the dryland areas of central Tanzania: impact of continuous application of traditional tillage practices. GeoJournal vol.71 No.2/3 pp 107-115

Statistics Botswana (2011) National population and housing census 2010. Ministry of Finance and Development Planning, Gaborone.

Stoller E, Nema D, Bhan V (1972) Yellow nutsedge tuber germination and seedling development. Weed Sci 20(1):93-97. https://doi.org/10.1017/ S0043174500035037

Stoller E, Sweet R (1987) Biology and life cycle of purple and yellow nutsedges (Cyperus rotundus and C. esculentus). Weed Technol 1(1):66-73

Streibig JC (1988) Weeds: the pioneer flora of arable land. Ecol Bull 39:59-62

Swanton CJ, Shrestha A, Roy RC, Ball-Coelho BR, Knezevic SZ (1999) Effect of tillage systems, $\mathrm{N}$ and cover crop on the composition of weeds flora. Weed Sci 47(4):454-461

Swanton CJ, Weise SF (1991) Integrated weed management: the rationale and approach. Weed Technol 5:657-663

Teuton TC, MacDonald GE, Main CL, Brecke BJ (2006) Characterization of fluazifop-P-butyl activity on bristly starbur (Acanthospermum hispidum). Weed Technol 20(3):717-721

Tsheboeng G, Bonyongo MC, Murray-Hudson M (2014) Influence of flood variation on seasonal floodplain vegetation communities in the Okavango Delta, Botswana. Afr J Aquat Sci 39(Ringrose et al.):77-87. https://doi.org/10. 2989/16085914.2013.878241

Yadav AS, Gupta SK (2005) Effect of micro environment and human disturbance on the diversity of woody species in the Sariska Tiger Project in India. Forest Ecol Manag 22(2006):178-189

Yenish JP, Doll JD, Buhler DD (1992) Effects of tillage on vertical distribution and viability of weed seed in soil. Weed Sci 40(3):429-433

\section{Submit your manuscript to a SpringerOpen ${ }^{\circ}$ journal and benefit from:}

- Convenient online submission

- Rigorous peer review

- Open access: articles freely available online

High visibility within the field

- Retaining the copyright to your article

Submit your next manuscript at $\boldsymbol{\nabla}$ springeropen.com 